\title{
Cognitive Domain Performance for Non- Laboratory Embedded and Laboratory Embedded Course
}

\author{
Rohaya Alias ${ }^{1}$, Noraida Mohd Saim², \\ Nur Asmaliza Mohd Noor ${ }^{3}$ and Siti Hawa Rosli ${ }^{4}$ \\ Faculty of Civil Engineering, Universiti Teknologi MARA Pahang \\ 26400 Bandar Tun Razak Jengka, Pahang, Malaysia \\ 1https://orcid.org/0000-0002-2129-2677 \\ 2https://orcid.org/0000-0002-1600-7720 \\ 3https:/ / orcid.org/0000-0001-7185-1628 \\ ${ }^{4}$ https://orcid.org/0000-0002-2955-9778
}

\begin{abstract}
This paper describes the students' performance in terms of the cognitive domain for non-laboratory embedded courses and laboratory embedded courses. The study sample consisted of the students enrolled in the non-laboratory embedded courses (Hydraulics and Soil Mechanics) and laboratory embedded courses (Basic Hydraulics and Basic Soil Mechanics) for Diploma in Civil Engineering programme. The cognitive assessment based on the level of cognitive of Bloom's Taxonomy which composes of knowledge, comprehension, application, analysis, synthesis, and evaluation. Methods of cognitive assessment for non-laboratory embedded courses differ from laboratory embedded courses. The cognitive assessment for non-laboratory embedded courses comes from $60 \%$ of the final exam, $30 \%$ of the test, and $10 \%$ of the assignment. Meanwhile, the cognitive assessment for laboratory embedded course is only through $60 \%$ of the final exam. The other evaluations for this course are $30 \%$ of practical tests (psychomotor domain) and 10\% of laboratory observation (affective domain). Since the assessment methods are different, this study was carried out to evaluate the students' performance on the cognitive domain for both courses. The percentage of students' marks in the coursework and final exam were analysed using a descriptive statistic to measure the students' performance. The results revealed that the students who through non-laboratory embeddedcourses scored a good result in final examination compared to laboratory embedded-courses. Hence, the findings of this study might help educators identifying the reliable and effective assessment method to improve the achievement of learning outcomes.
\end{abstract}

Keywords: assessment; cognitive domain; descriptive statistic; students' marks; students' performance 


\section{Introduction}

Education management in Malaysia has evolved progressively to achieve Malaysia's aspiration to be a developed country. Due to the rapid and sustainable transformation of the education system by 2025, the Education Blueprint has been designed by the government to provide a comprehensive plan (MOE, 2013). However, the education system has been criticized by the industries due to the low performance of graduates and unable to apply the knowledge and skill learned into the job task (Muniapan, 2007).

Evaluation on the way of the teaching process is widely conducted in higher educations as this approachable to contribute to the researchers to identify the factors that undermine the learning process. Numerous factors are influencing the learning process starts with students' expectation, teaching material such as course material, method of teaching, instructor/lecturers' competency and the environment of the class (Cho \& Cho, 2017). All these factors contribute significantly to the performance of students either in the school or higher institution. Hence, it is very important to conduct students' evaluation to provide important and useful information thus this will help to improve teaching quality among the educators/lecturers. Findings from the students' evaluation may help the instructors/ lecturers and university to improvise their weakness according to the comments given by students (Cho \& Baek, 2019).

Currently, there are various assessment methods for courses developed and implemented in higher education to produce more graduates who meet the market demand. The assessment methods are one of the elements that can impact the students' academic performance. However, the results of research that measures their impact on performance are inconclusive (Sacristán-Díaz et al., 2016).

Assessment is an essential element in any educational process. The definition of assessment in education consists of the methods and procedures required by the instructor to measure and evaluate the developmental stages of student learning as well as achievement of skills (Glossary of Education Reform, 2015). The assessment is a dynamic and multi-faceted process with variable aims (Anaf \& Yamin, 2014). The knowledge and skills that students have acquired from the learning session can be evaluated (Vergis \& Hardy, 2009). According to Brown et al. (2013), the assessment can determine what students think is important and how they spend their time and effort in reviewing and studying. Suskie (2004) argues that assessment can prove measurable student learning outcomes and provisioning an adequate measure of learning to reach these results. Also, the implementation of well-organized methods of assessment with complete analysis can provide the evidence to determine the requirement for learning. Moreover, assessment is necessary to plan further steps for the improvement of teaching and learning.

\subsection{Engineering Courses in Malaysia University}

The assessments of engineering students in Malaysia are based on the learning outcome achievement as stated in the Engineering Technology Accreditation 
Council (ETAC) 2019 Manual that requires diploma graduates to satisfy the minimum academic and practical requirement in enabling them to register as an engineering technician/ inspector. Therefore, the university has aligned all the subjects according to the stated requirement by ETAC (BEM, 2019). The design of the assessment was according to the Bloom Taxonomy, which comprises of 3 domains; cognitive (C), psychomotor (P) and affective (A) within the specific criteria and standards. However, these tasks are quite challenging as they have to align to achieve meaningful learning experience (Shelena et al., 2017 \& University of New South Wales, 2017).

Bloom's taxonomy is a different set of targets and abilities that educators use to achieve learning objectives. Chung (1994), Lewy \& Bathory (1994) and Postlethwaite (1994) agreed to stated that the Bloom's taxonomy of the cognitive domain is one of the basic systems for categorizing the aims of educational, curriculum, and it also uses for test preparation around the world. The cognitive domain acquires processes and utilizes the knowledge, focuses on intellectual skills, and it is more to thinking domain. This domain is the core domain in the learning system. The level involved in this domain is knowledge, comprehension, application, analysis, synthesis and evaluation (Bloom, 1956). The development of a curriculum that increases the level of cognitive skills may encourage the academic performance and long-term success of the students (Finn et al., 2014). The cognitive domain can be delivered through lecture using online or face to face method. The measurement of this domain achievement was by exams, tests, assignments and quizzes. The cognitive domain is simple to assess compared with psychomotor and affective domains. The psychomotor domain depicts physical and kinesthetic skills. The level of progressive behaviour defines it from monitoring to mastery of physical skills. Commonly, the development of psychomotor skills is in the laboratory setting, and by carrying out practical tests would measure those skills. Furthermore, the affective domains are related to feelings or emotions (attitude) throughout the learning experience. It expressed through views, opinions or beliefs (Smith \& Ragan, 1999). Group project, competition, report and presentation are kind of assessments to measure the attainment of the affective domains. According to Bednar \& Levie (1993), actions and behaviours can reflect a person's attitude.

Course Outcome (COs) is a target learning and teaching process for the courses. The COs highlighted the outcomes that students should able to understand throughout the semester. Normally, students' ability will be evaluated based on the listed COs at the end of the semester. According to Gowrishankar et al. (2014), good performance students can be produced by educators through incorporating all domains of cognitive, psychomotor and affective into the course, especially for courses offered in higher education such as universities. Students who passed that course should gain all the knowledge and achieved the designated COs. Thus, it is essential to conduct the assessment on the COs to see the results (Kasilingam et al., 2014).

Meanwhile, the programme outcomes is a students' expectation and their performance upon graduation. Generally, the students' performance related to the 
skills, knowledge and attitude that they had gained throughout the study period. As required by BEM through ETAC Manual 2019, there are 12 Programme Outcomes (POs) need to be delivered to the student upon their graduation(BEM, 2019). The 12 Programme Outcomes are as follows;

PO1: Students should have fundamental knowledge related to science and mathematics.

PO2: Students should be able to analyse the specific problem related to the application of engineering.

PO3: Students should occupy with the design of the solution for a specific problem by considering the health and safety, environment and social aspect.

PO4: Students should able to know how to conduct the investigation using the catalogues, standard test and measurement on given problems.

PO5: Students should able to use the appropriate modern techniques, resources and information technology to solve the specific engineering problem.

PO6: Students should able to know about the safety, legal and social. Thus, this can help to solve a specific problem related to the application of civil engineering.

PO7: Students should have knowledge and understanding of the environment and sustainability. Thus, this to help them to solve any given problem that related to the environment and societal.

PO8: Students should understand their role and should adhere the professional ethics as a civil technician.

PO9: Students should have the skill to act efficaciously as an individual and as a member of a team.

PO10: Students should able to have effective communication skill; thus, this leads them to communicate on the given problem, give and receive the instruction when involved with the engineering project.

PO11: Students should have an understanding of how to manage the engineering project and finance and able to manage projects in various disciplinary. They should able to have the skill as a technical team or as a leader in the assigned project.

PO12: Students should be able to have the skill to participate in independent learning and able to engage with the latest information or techniques in civil engineering.

This 12 POs divided into the cognitive, psychomotor and affective domain. PO1, $\mathrm{PO} 2$ and PO3 can be classified under the cognitive domain as they are used to measure the knowledge and problem solving, which closely related to the cognitive. Meanwhile, the psychomotor domain contributed through PO4 and PO5, which related to the skills and practices used by the students to solve the given problem. Moreover, PO6, PO7, PO8, PO9, PO10, PO11 and PO12 are related to the affective domain because these POs related to the students' attitude and feelings. 


\subsection{Literature Review}

Many of existing papers discussed on students' performance according to the domains (cognitive, psychomotor or affective) (Gregory, 2019; Anaf \& Yamin, 2014; Tam, 2014; Martone \& Sereci, 2009) but only a little-discussed on the embedded course (Schuijers et al., 2013). The discussion on the embedded course by Schuijers et al. (2013) on the effectiveness of separating the theoretical part and practical part in physiology courses. Hairuddin et al. (2018) state that embedded courses greatly influence the achievement of culinary arts students. The results of his study have found that the students cannot achieve good performance if they only show cooking skills, but lack in terms of cognitive level. To achieve good performance, the ability to think, understand and apply must also be given. According to Ajumunisha Ali Begam \& Tholappan (2018), overall assessment incorporating all learning domains for each course is essential to produce skilled and knowledgeable graduates of any higher education programme. Since there were two different cohorts with two different nature of courses (embedded and non-embedded course) involved for Diploma of Civil Engineering programme, it is a good chance to make the comparison on the cognitive domain between the embedded and non-embedded courses. Thus, the study aims to evaluate the students' performance in terms of the cognitive domain for non-laboratory embedded courses and laboratory embedded courses. The initial drive was to validate which type, of course, perform well in term of the cognitive domain. Besides, findings from this paper can be part of continual quality assessment for faculty level for better improvement in the future.

\subsection{Description of Course}

Hydraulics (ECW241)

This course covers the application of the energy equation on in-compressible pipe flow, analysis of pipe network and the design of the open channel based on uniform flow condition. Also, this course included the application of specific energy concept and momentum equation for the analysis of non-uniform flow and analysis of pump operation and performance. This course addresses the programme outcome which related to the fundamental and application solution and problem-solving using well-defined engineering problem.

\section{Soil Mechanics (ECG243)}

Soil Mechanics deal with the basic principles of soil that related to the concept of effective stress, the process of consolidation and soil shear strength behaviour. The topic of physical properties and classification of soil, the flow of water through soil, shear strength, and soil compaction and consolidation are discussed in this course as well. This course addresses the programme outcome related to the fundamental and application solution in a well-defined engineering problem.

\section{Basic Hydraulic (ECW321)}

The Hydraulic Engineering explains fluid behaviour such as steady incompressible flow in a pipe, flow uniformly and non-uniformly in an open channel and types of machinery such as turbine and pump. This course addresses the programme outcome which related to the fundamental and application solution, problem-solving using well-defined engineering problem, conducting 
the standard laboratory test for soil engineering and having knowledge on the safety issues with accordance the engineering technician practices.

Basic Soil Mechanics (ECG303)

This course deals with the basic principles of soil mechanics. It covers topics on physical properties and classification of soil, shear strength, the flow of water through soil, soil compaction and consolidation. Besides, this course also provides exposure to students on procedures of standard laboratory for soil tests. This course addresses the programme outcome which related to the fundamental and application solution, problem-solving of a well-defined engineering problem, conducting the standard laboratory test for soil engineering and having knowledge on the safety issues with accordance the engineering technician practices.

\subsection{Assessment Method}

According to the different cohort, there are two different types of assessment known as non-laboratory courses embedded in the main course (Group 1) and laboratory courses embedded in the main course (Group 2). The contact hour for the course under Group 1 is 4 hours which comprises of 3 hours lecture and 1hour tutorial while as the contact hour for the course under Group 2 is 5 hours which includes lecture (2 hours), tutorial (1-hour), and laboratory activities (2 hours). The courses under Group 1 are Hydraulic (ECW241), and Soil Mechanics (ECG243), and the assessment comes from $60 \%$ of the final exam (cognitive domain) and $40 \%$ of the coursework. The coursework assessments divided into $30 \%$ of the test (cognitive domain) and $10 \%$ of assignment (cognitive domain). Meanwhile, the courses under Group 2 are Basic Hydraulic (ECW321) and Basic Soil Mechanics (ECG303) where the assessment contributed through $60 \%$ of the final exam (cognitive domain) and $40 \%$ of the coursework. The assessment of coursework consists of $30 \%$ of practical tests (psychomotor domain) and $10 \%$ of laboratory observation (affective domain). The summary of the assessment methods for all the courses shown in Table 1.

Table 1: Assessment method for courses under Group 1 and Group 2

\begin{tabular}{|c|c|c|c|}
\hline Group & Course & Method of Assessment & Domain \\
\hline \multirow{2}{*}{$\begin{array}{c}1 \\
\text { (Non-laboratory } \\
\text { embedded } \\
\text { courses ) }\end{array}$} & $\begin{array}{l}\text { Hydraulic } \\
\text { (ECW241) }\end{array}$ & \multirow{2}{*}{$\begin{array}{c}60 \% \text { of Final exam } \\
30 \% \text { of Test } \\
10 \% \text { of Assignment }\end{array}$} & \multirow{2}{*}{$\begin{array}{l}\mathrm{C} \\
\mathrm{C} \\
\mathrm{C}\end{array}$} \\
\hline & $\begin{array}{l}\text { Soil Mechanics } \\
\text { (ECG243) }\end{array}$ & & \\
\hline \multirow{2}{*}{$\begin{array}{c}2 \\
\text { (Laboratory } \\
\text { embedded } \\
\text { courses ) }\end{array}$} & $\begin{array}{l}\text { Basic Hydraulic } \\
\text { (ECW321) }\end{array}$ & \multirow{2}{*}{$\begin{array}{c}60 \% \text { of Final exam } \\
30 \% \text { of Practical tests } \\
10 \% \text { of Laboratory observation }\end{array}$} & \multirow{2}{*}{$\begin{array}{l}\mathrm{C} \\
\mathrm{P} \\
\mathrm{A}\end{array}$} \\
\hline & $\begin{array}{c}\text { Basic Soil Mechanics } \\
\text { (ECG303) }\end{array}$ & & \\
\hline
\end{tabular}


Meanwhile, the cognitive level among these courses should follow the allocation that already specified through the table of difficulties (Table 2). The cognitive level has divided into three segments which are low level comprises of knowledge (C1) and comprehension (C2), intermediate level consists of application (C3) and analysis (C4), and higher-level comprises of synthesis (C5) and evaluation (C6). The assessments of courses mentioned in this paper have designed following the table of difficulties. The allocation marks for assessment involved such as assignment, tests and final examination.

Table 2: Cognitive Level and Percentage Level of Difficulty (\%)

\begin{tabular}{|c|c|c|c|c|c|c|}
\hline Year & \begin{tabular}{|c|}
$\mathrm{C} 1$ \\
Knowledge
\end{tabular} & $\begin{array}{c}\text { C2 } \\
\text { Comprehension }\end{array}$ & $\begin{array}{c}\text { C3 } \\
\text { Application }\end{array}$ & $\begin{array}{c}\text { C4 } \\
\text { Analysis }\end{array}$ & $\begin{array}{c}\text { C5 } \\
\text { Synthesis }\end{array}$ & $\begin{array}{c}\text { C6 } \\
\text { Evaluation }\end{array}$ \\
\hline 1 & & $30-45$ & \multicolumn{2}{|c|}{$45-65$} & \multicolumn{2}{|c|}{$10-25$} \\
\hline 2 & & $20-35$ & \multicolumn{2}{|c|}{$40-60$} & \multicolumn{2}{|c|}{$20-35$} \\
\hline 3 & & $10-25$ & \multicolumn{2}{|c|}{$45-55$} & \multicolumn{2}{|c|}{$30-45$} \\
\hline
\end{tabular}

Since the methods of assessment and approach are different between the courses of Group 1 and Group 2, therefore this study presents the students' performance on the cognitive domain for all courses of both groups.

\subsection{Research Questions}

Research questions can be summarized as follows;

i. What is the trend of students' performance for the different courses in the non-embedded course and embedded course?

ii. What is the failure rate of students in the non-embedded course and embedded course?

iii. Is there any significant difference in the performance between the nonembedded course and embedded course?

iv. What is the students' perception of teaching and learning for all the courses in the non-embedded course and embedded course?

\section{Research Method}

The courses of Group 1 and Group 2 have designed for second-year of Diploma in Civil Engineering programme, Universiti Teknologi MARA. The study has conducted for TWO (2) different cohort of students which was in June 2017 for Group 1 (G1) and in June 2016 for Group 2 (G2) to achieve the objectives of the study. These cohorts are taught by the same lecturer, which were four (4), instructors/lecturers, for ECG243 and ECG 303 and 3 instructors/lecturers for ECW241 and ECW321.

A total of 275 students of ECW241, 336 students of ECW321, 375 students of ECG243 and 406 students of ECG303 are the sample in this study and the selection of these students according to the total number of students who registered of these courses. The enrolment of these courses was subjected to the students must pass the pre-requisite courses thus, indicated only students who take these courses for the first time are involved in this study. The students' results were obtained from 
the Academic Affairs Division (Examination Unit) and as such, were assumed to be valid and reliable. The collected students' results were analysed to evaluate the students' performance, and the analysis is made based on the overall achievement comprising the percentage (\%) of marks obtained for the courses. Descriptive statistical analysis of the data involving simple frequency counts of the score has applied for each performance results. Also, the significant test using t-test method has carried out to evaluate whether any significant difference of the achievement for non-embedded and embedded courses. Besides, the comparison of the result between gender also conducted to identify the difference of performance between male and female students.

At the end of the semester, students' evaluation survey has been conducted to gauge the students' perception of these courses which related to the learning activities and overall perception on the subjects and the results have been rate according to the Table 3.

Table 3: A rating system for students' perception

\begin{tabular}{|c|c|}
\hline Students' evaluation & Rating \\
\hline $3.60-4.00$ & Excellent \\
\hline $3.20-3.59$ & Very good \\
\hline $2.80-3.19$ & Good \\
\hline $2.40-2.79$ & Average \\
\hline Below 2.40 & Weak \\
\hline
\end{tabular}

\section{Result and Discussion}

\section{Samples of the study}

Table 4 shows the details of the samples in this study. All the students enrolled in those courses was selected in this study to produce a precise analysis of overall performance. Around $50 \%-54 \%$ of the students were male students enrolled in ECW241, ECG243 and ECG303, while 53.27\% of female students dominated the course of ECW321. Hence, the distribution of the enrollment between male and female seem to balance for all the courses.

Table 4: The total number of students enrolled in courses under Group 1 and Group 2

\begin{tabular}{|c|c|c|c|c|c|c|}
\hline Group & Course & Male & Percentage (\%) & Female & Percentage (\%) & Total \\
\hline \multirow{2}{*}{ Group 1 } & ECW241 & 140 & 50.91 & 135 & 49.09 & 275 \\
\cline { 2 - 7 } & ECG243 & 202 & 53.87 & 173 & 46.13 & 375 \\
\hline \multirow{2}{*}{ Group 2 } & ECW321 & 157 & 46.73 & 179 & 53.27 & 336 \\
\cline { 2 - 7 } & ECG303 & 204 & 50.25 & 202 & 49.75 & 406 \\
\hline
\end{tabular}


Students' Performance on the Cognitive Domain

Figure 1 indicates the students' performance on the cognitive domain for the course ECW241 and ECW321 according to the grade obtained. The results indicated, $81.8 \%$ of students for ECW241 had passed this course with the minimum grade was C, meanwhile, as for ECW321, around 13.7\% from the 336 total number of students had passed this course with the minimum of the grade was $\mathrm{C}$ as well. Furthermore, Figure 2 displays the students' performance for the course of ECG243 and ECG303. The results show that $80.5 \%$ of students passed ECG243 compare to ECG303, which only $58.6 \%$ of students had passed the course. From both figures, the findings indicated that the students who enrolled in nonembedded courses score higher results for cognitive domain compare the students who enrolled in the embedded courses.

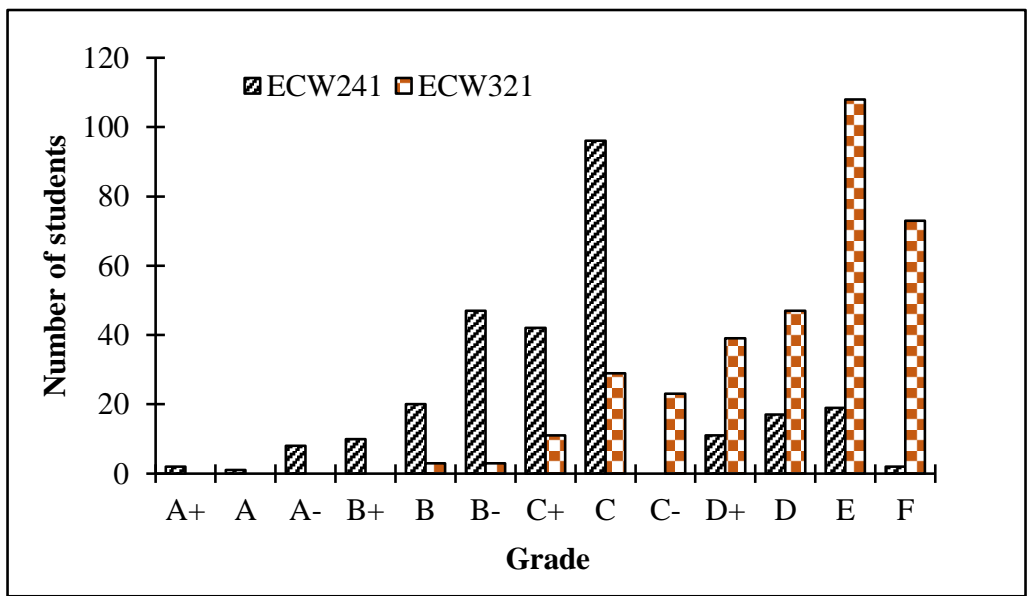

Figure 1: Students' performance on the cognitive domain for ECW241 and ECW321

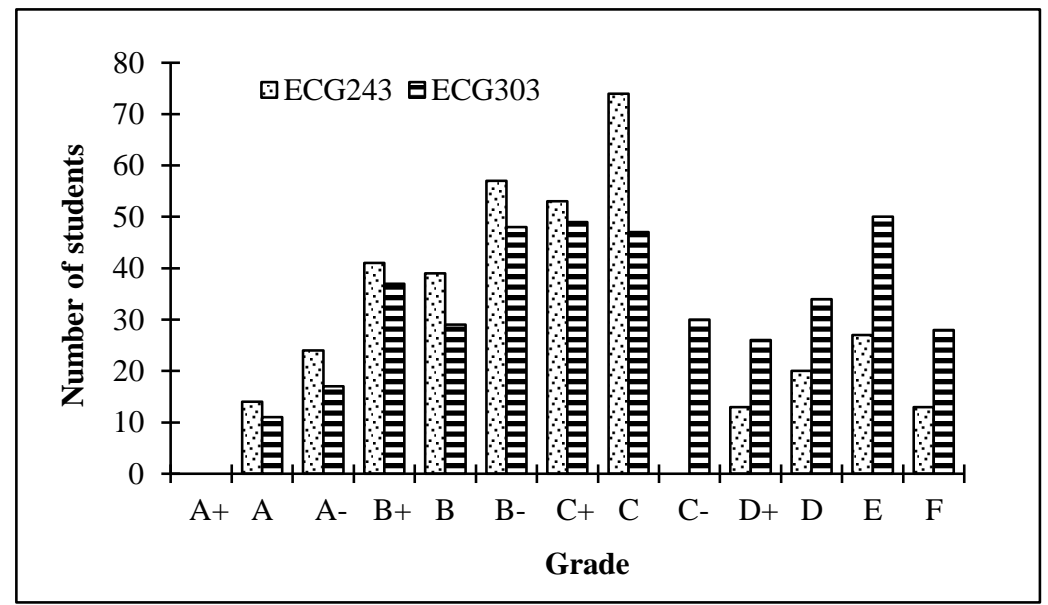

Figure 2: Students' performance on the cognitive domain for ECG243 and ECG303

Figure 3 summarized the percentage of failure for all the courses in Group 1 and Group 2 that show the distribution of failure grade which are C-, D+, D, E and F. The trend clearly show that the cognitive assessment of non-embedded courses (G1) contributed a low percentage of failure which are less than $8 \%$. Compared 
with the embedded courses (G2) that the cognitive domain shows the failure rate up to $32 \%$.

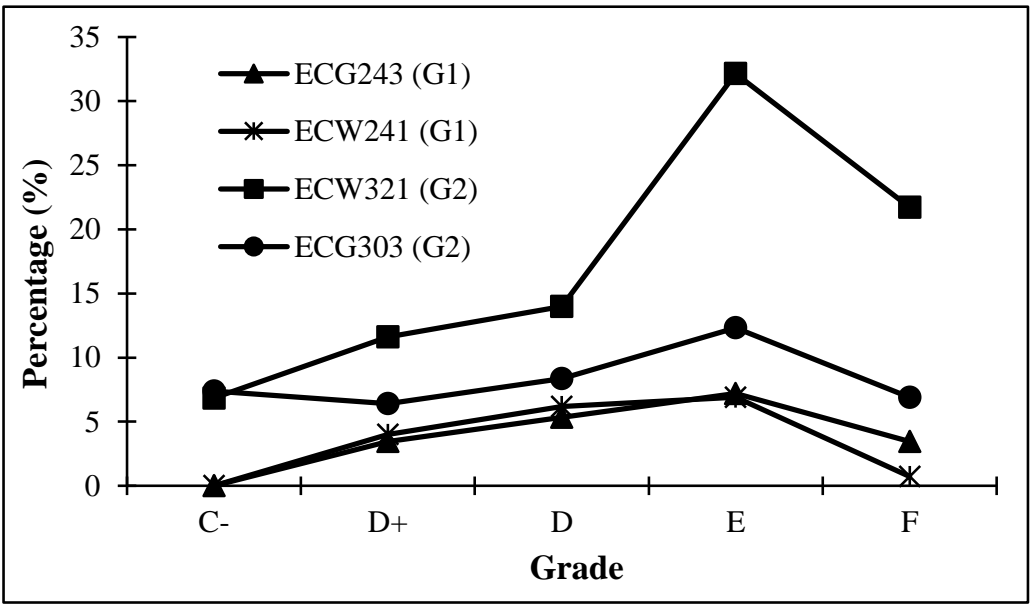

Figure 3: Percentage of failure on the cognitive domain for Group 1 and Group 2 courses

The main contributing factor of such finding for non-embedded courses is that students have already experienced other cognitive assessments such as test and assignment in their continuous coursework evaluation. Therefore, these assessments indirectly enhance their understanding and performance of cognitive assessment in the final exam. Compared to the embedded-courses, the cognitive domain assessment solely depended on the final examination. Thus, only a small number of students able to cope with it and score good results during the final exam. Therefore, this way indirectly able to segregate a good and focus student who always consistently try to understand and study with the students who did not. However, this result slightly differences with the study conducted by Antoni et al. (2019) where the finding indicated students who enrolled embedded subjects score higher mark in final exam compared to students who did not.

Table 5 shows the descriptive analysis for ECW241, ECW321, ECG243 and ECG303. The median for ECW241 and ECW321 are 54.5 and 38.5, respectively. While the descriptive analysis for ECG243 and ECG303 also shows that the median and standard deviation for both courses differ slightly. Based on the overall standard deviation, maximum and minimum, it indicates that the marks attained vary widely around the mean for all the courses. The t-test also confirmed that the achievement of ECG243 and ECG303 differ significantly with the p-value less than 0.05. A similar t-test finding between ECW241 and ECW321 showing the significant difference with the p-value is 0.018 (also less than 0.05 ).

Table 5: Descriptive analysis marks attained by the students

\begin{tabular}{|c|c|c|c|c|c|c|c|}
\hline $\begin{array}{c}\text { Course } \\
\text { Code }\end{array}$ & $\begin{array}{c}\text { Total } \\
\text { Students }\end{array}$ & Mean & Median & $\begin{array}{c}\text { Standard } \\
\text { Deviation }\end{array}$ & Maximum & Minimum & $\begin{array}{c}\text { t-test } \\
\text { (p-value) }\end{array}$ \\
\hline ECW241 & 275 & 54.50 & 54.00 & 10.14 & 92.35 & 27.00 & \multirow{2}{*}{0.018} \\
\hline ECW321 & 336 & 37.51 & 38.50 & 10.98 & 68.00 & 0 & \\
\hline
\end{tabular}




\begin{tabular}{|l|l|l|l|l|l|l|l|}
\hline ECG243 & 375 & 57.10 & 57.83 & 13.57 & 87.54 & 14.05 & \multirow{2}{*}{$1.6 \times 10^{-5}$} \\
\cline { 1 - 6 } ECG303 & 406 & 52.65 & 53.00 & 15.11 & 86.50 & 4.50 & \\
\hline
\end{tabular}

From this finding, it shows the students who sit for ECW241 and ECG243 demonstrated an excellent achievement on the cognitive level compared to the students who sit for ECW321 and ECG303. The reason behind this, the students who sit for ECW241 and ECG243 had experienced the cognitive level from coursework assessment until final exam stage compared to the students who sit for ECW321 and ECG303 who just go through the cognitive level in the final exam stage. The training attained by ECW241 and ECG243 students had contributed to the excellent achievement grades compared to ECW321 and ECG303.

\section{Students' Performance on the Cognitive Domain based on Gender}

Figure 4 and 5 show the performance of students for both courses; ECW241 and ECW321 based on gender. The result indicated that $37.4 \%(103 / 275)$ of male students for ECW241 who had passed this course. Meanwhile, 44.7\% (123/275) of female students had passed. As for ECW321, 2.98\% (10/336) of male students and $10.71 \%(36 / 336)$ of female students had passed this course. Moreover, Figure 6 and 7 also show the students' performance based on gender for ECG243 and ECG303. From the chart, it exposes that $41.8 \%$ of male students and $38.7 \%$ of female students had passed the ECG243 course. Meanwhile, 36.5\% of female students and $22.2 \%$ of male students had passed the ECG303 course.

From these findings show, the female students score better achievement in the cognitive domain compared to the male students. The factors that contribute to this finding due to female students are more hardworking in doing exercise and more focus during the class compared to the male students. The study conducted by Jones et al. (2013) on the first-year university students found that female students were more to get better results in engineering and math courses to compare than the male student. These finding also supported by Burns \& Bracey (2001); Clark, Oakley \& Adam (2006) were found that the female students' achievement was prominent than the male student in some of the school success. However, these findings might contradict with the study conducted by Joscha \& Thomas (2012), where boys did as well or better than girls in mathematics. 


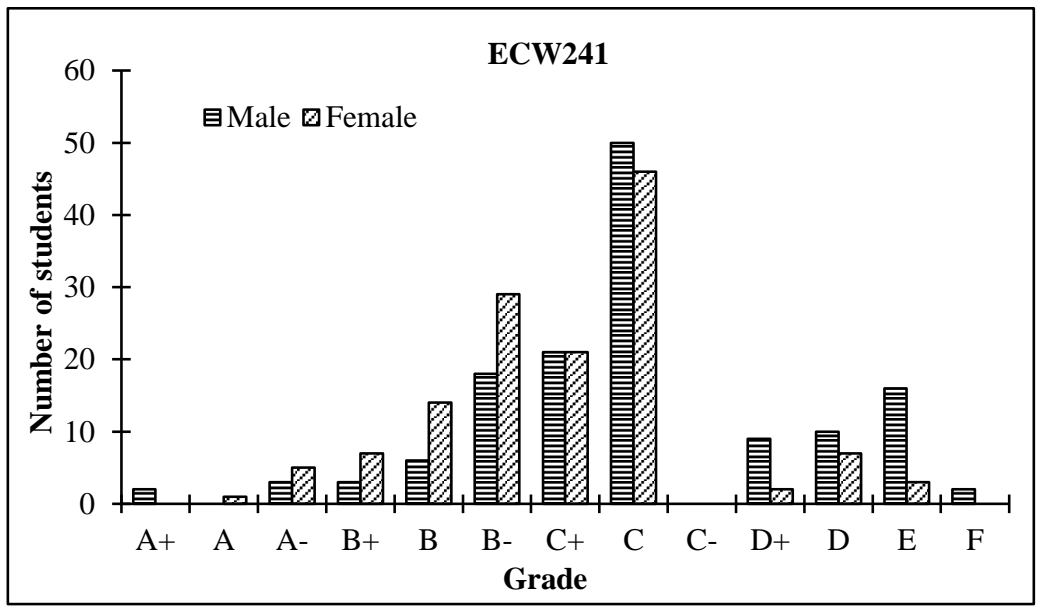

Figure 4: Students' performance for ECW241 based on gender

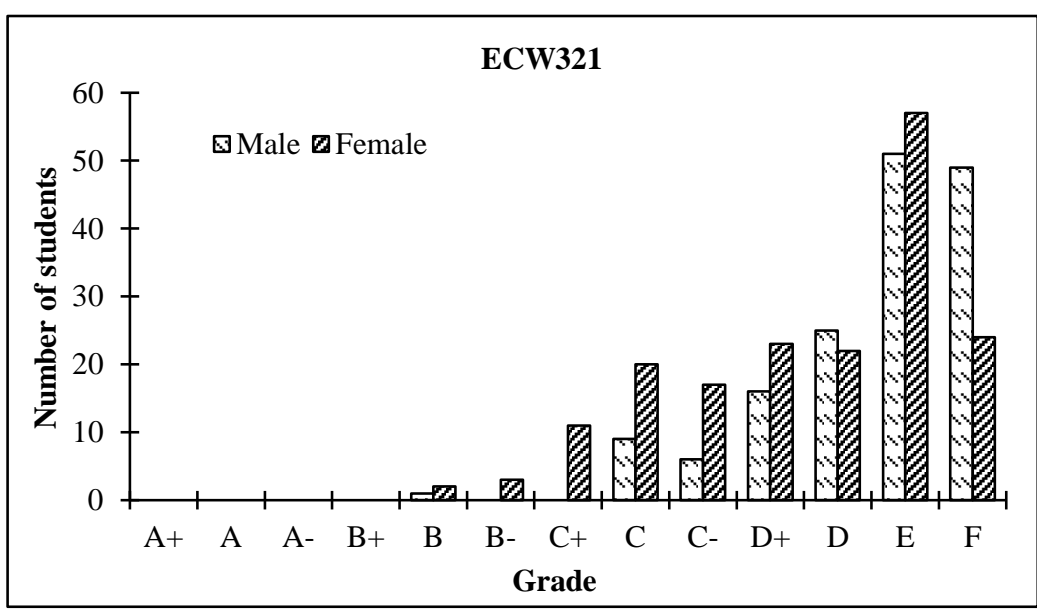

Figure 5: Students' performance for ECW321 based on gender

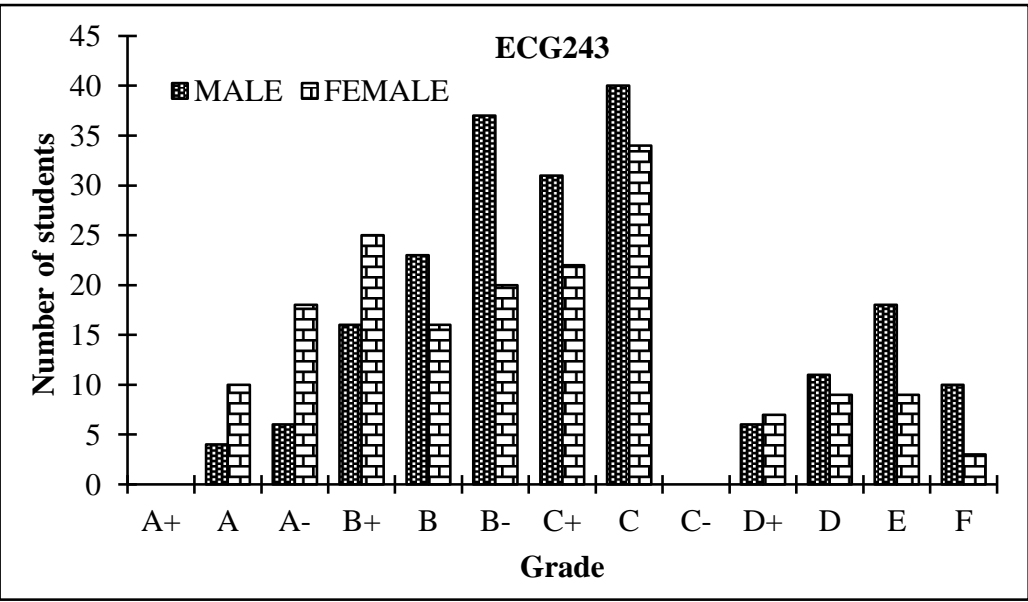

Figure 6: Students' performance for ECG243 based on gender 


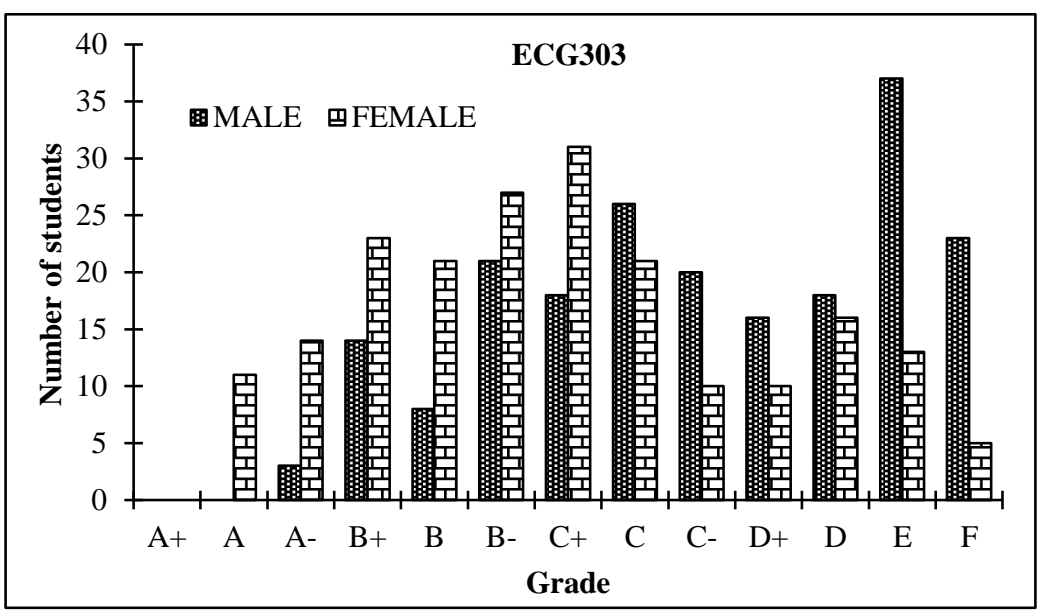

Figure 7: Students' performance for ECG303 based on gender

\section{Students' Perception}

Despite students' assessment, Gregory (2019) also highlighted the teaching and learning activities importance to influence the students' performance. Table 6 displays the students' overall perception of the course and the learning that they involved during the process of teaching and learning. The results show all courses attained very good remark with the score around 3.29 until 3.43 and it indicates that they have undergone the same process in the teaching and learning activities. These findings significantly showed, even though the approaches and methods of teaching were similar, still it depends on the ability of the students to cope with the assessments and nature of the course either embedded or non-embedded. Nevertheless, the instructor/lecturer need to encourage students to do more exercises to enhance their understanding of these courses. Therefore, to achieve a good grade and increase the performance of the cognitive domain, especially in embedded courses, concerted efforts between instructor/lecturer and students should be further enhanced.

Table 6: Students' perception of the ECW241, ECW321, ECG243 and ECG303

\begin{tabular}{|c|r|c|c|}
\hline Subject & Items & Score & Remarks \\
\hline \multirow{2}{*}{ ECW241 } & The overall perception of the subject & 3.33 & \multirow{2}{*}{ Very good } \\
\cline { 2 - 3 } & Learning activity & 3.29 & \\
\hline \multirow{2}{*}{ ECW321 } & The overall perception of the subject & 3.31 & \multirow{2}{*}{ Very good } \\
\cline { 2 - 3 } & Learning activity & 3.33 & \\
\hline \multirow{2}{*}{ ECG243 } & The overall perception of the subject & 3.43 & \multirow{2}{*}{ Very good } \\
\cline { 2 - 3 } & Learning activity & 3.43 & \\
\hline \multirow{2}{*}{ ECG303 } & The overall perception of the subject & 3.38 & \multirow{2}{*}{ Very good } \\
\cline { 2 - 3 } & Learning activity & 3.34 & \\
\hline
\end{tabular}




\section{Conclusion}

This study indicates that the students' performance on the cognitive domain for non-laboratory course-embedded (Group 1) better than laboratory courseembedded (Group 2). Simultaneously, the percentage of students with good grades (A+, A and $\mathrm{A}-)$ in the final examination for courses under Group 1 is higher than Group 2. Additionally, the proportion passing for courses under Group 1 in the final exam is also higher than courses under Group 2. Based on descriptive analysis, it shows Group 1 demonstrated an excellent achievement on the cognitive level compared to the Group 2 meanwhile the t-test also confirmed that the achievement of Group 1 and Group 2 differ significantly with the p-value < 0.05. To summarize the findings, the assessment method plays a prominent role in the education process as it affects the students' performance. The implemented assessment method of coursework using a test (cognitive domain) and assignment (cognitive domain) for courses under Group 1 was found more appropriate to improve the students' performance in the final exam. The reason is, the students have an understanding of the steps to respond to the final exam questions based on the test or assignment questions. In contrast to courses under Group 2, which is the assessment method of coursework using practical tests (psychomotor domain) and laboratory observation (affective domain). The laboratory is more than just gaining knowledge. It is about doing and learning through experiences. Therefore, to improve students achievement in the cognitive domain for laboratory-embedded courses, the current assessment method can be revised. Perhaps, the test also could be included in the coursework assessment. The study also revealed that the female students score better accomplishment in the cognitive domain contrasted with the male students. Hence a few improvements must make to increase the male student awareness about the importance of the academic performance of the cognitive domain. In conclusion, the findings of this study can serve as a reference to help educators identifying the most reliable and advantageous assessment method regarding the educational process.

\section{Limitation and Recommendation}

This study only focuses on two courses for non-laboratory embedded-courses and two courses for laboratory embedded-courses. Thus, it does not represent the whole courses of non-laboratory embedded and laboratory embedded course for Diploma in Civil Engineering programme. Based on the limitation of this study, it strongly advised increasing the number of other courses for data analysis. This study was also limited to the courses for Diploma in Civil Engineering programme.

From this study, there is evidence that the students' performance on the cognitive domain for non-laboratory course-embedded was better than laboratory courseembedded. However, there is a need for further research. Future research may address:

i. Focus on factors that influence students' performance on the cognitive domain better for non-laboratory course-embedded compare with laboratory course-embedded. 
ii. To investigate in-depth the effective teaching and learning approaches based on gender by interviewing the students.

iii. To design a guideline on how to develop an effective cognitive learning process.

\section{References}

Ajumunisha, A. B. A., \& Tholappan, A. (2018). Psychomotor domain of bloom's taxonomy in teacher education. Shanlax International Journal of Education, 6(3), 11-14. https://doi.org/10.5281/zenodo.1299766

Anaf, Y. S., \& Yamin, S. B. (2014). Difference and similarity of continuous assessment in Malaysian and Nigerian universities. Journal Education Practice, 5(1), 73-82.

Antoni, P., Fermin, S. C., Nuria, S., \& David, L. (2019). Cooperative learning and embedded active learning methodologies for improving students' motivation and academic results. International Journal of Engineering Education, 35(6A), 1-8.

Barkley, A. (2006). The determinants of college student performance: The role of the assessment method. Paper presented at the WAEA annual meeting, Alaska, USA.

Bednar, A., \& Levie, W. H. (1993). Attitude-change principles. In M. Fleming \& W. H. Levie (Eds.), Instructional message design: Principles from the behavioural and cognitive Publications. sciences (pp. 283-304). Englewood Cliffs, NJ: Educational Technology

Bloom, B. S. (1956). Taxonomy of educational objectives: The classification of educational goals. Handbook 1: Cognitive domain. New York: Longman.

Board of Engineer Malaysia (BEM). (2019). Engineering Technology Accreditation Council Manual 2019. Retrieved from: http://bem.org.my/engineering-technologyaccreditation-council

Brown, G. A., Bull, J., \& Pendlebury, M. (2013). Assessing student learning in higher education. Routledge. New York: USA.

Burns, J., \& Bracey, P. (2001). Boys' underachievement: Issue, challenges and possibilities wats forward. Westminster Studies in Education, 24(2), 155-166. https://doi.org/10.1080/0140672010240206

Clark, M. A., Oakley, E., \& Adam, H. (2006). The gender achievement gap challenge. ASASchool Counselor, 43(3), 20-25.

Cho, J., \& Baek, W. (2019). Identifying factors affecting the quality of the teaching in basic science education: Physics, biological, sciences, mathematics, chemistry. Sustainability, 11(3958), 1-18. https:/ / doi.org/10.3390/SU11143958

Cho, D., \& Cho, J. (2017). Does more accurate knowledge of course grade impact teaching evaluation?. Education Finance Policy, 12, 224-240. https://doi.org/10.1162/EDFP_a_00197

Chung, B. M. (1994). The taxonomy in the republic of Korea. In Anderson, L. W., and Sosiak, L. A. (Eds), Bloom's taxonomy: A forty-year retrospective, Ninety-third yearbook of the national society for the study of education (pp. 363-173). Chicago: University of Chicago Press.

Finn, A. S., Kraft, M. A., West, M. R., Leonard, J. A., Bish, C. E., Martin, R. E., Sheridan, M. A., Gabrieli, C. F. O., \& Gabrieli, J. D. E. (2014). Cognitive skills, student achievement test and schools. Psychological Science, 25(3), 736-744. https://doi.org/ 10.1177/0956797613516008

Gowrishankar, K., Mritha, R., \& Elanchezian, C. (2014). Assessment of learning domains to improve student's learning in higher education. Journal of Young Pharmacists, $6(4), 27-33$. 
Gregory, A. D. L. (2019). Academic performance and assessment. Educational Psychology, 39(6), 705-708. https://doi.org/ 10.1080/01443410.2019.1625522

Hairuddin, H., Abdul Wafi, A. R., Noorazman, A. S., Siti Noor Fazelah, M. N., \& Adibah Aishah, M. S. (2018). The effectiveness of cognitive and psychomotor domain of culinary art students' performance after internship in private colleges. MATEC Web of Conferences 150 (05021), https:// doi.org/10.1051/matecconf/201815005021

Hassan, O. A. B. (2011). Learning theories and assessment of methodologies-an engineering educational perspective. European Journal of Engineering Education, 36(4), 327-339. https://doi.org/10.1080/03043797.2011.591486

Jones, B., Ruff, C., \& Parett, M. (2013). The impact of engineering identification and stereotypes on undergraduate women's achievement and persistence in engineering. Social Psychology of Education, 16(3), 471-493.

Joscha, L., \& Thomas, A. D. (2012). School context and the gender gap in educational achievement. American Sociological Review, 77(3), 463-485. https://doi.org/10.1177/0003122412440802

Kasilingan, G., Ramalingam, M., \& Chinnavan, E. (2014). Assessing the learning domain to improve student's learning in higher education. Journal of Young Pharmacist, $6(4), 27-33$.

Lewy, A., \& Bathory, Z. (1994). The taxonomy of educational objectives and continental Europe, the Mediterranean, and the Middle East. In Anderson, L. W., and Sosiak, L. A (Eds), Bloom's taxonomy: A forty-year retrospective, ninety-third yearbook of the national society for the study of education ( $p p$. 146-163). Chicago: University of Chicago Press.

MOE. (2013). Malaysia Education Blueprint 2013-2025, Preschool to post-secondary education. Retrieved from:

https://www.moe.gov.my/menumedia/mediacetak/penerbitan/dasar/1207malaysia-education-blueprint-2013-2025/file

Muniapan, B. (2007). Issue and Challenges of Management Education in Malaysia. Working Paper, Curtin University of Technology, 1-12. Retrieved from: http://eprints.um.edu.my/31/1/balakrishnan.pdf

Picard, R. W., Papert, S., Bender, W., Blumberg, B., Breazeal, C., Cavallo, D., Machover, T, Resnick, M., Roy, D., \& Strohecker, C. (2004). Affective learning-a manifesto. B T Technology Journal, 22(4), 253-269. https://doi.org/10.1023/b:bttj.0000047603.37042.33

Postlethwaite, T. N. (1994). Validity vs utility: Personal experiences with the taxonomy. In Anderson, L. W., and Sosiak, L. A (Eds), Bloom's taxonomy: A forty-year retrospective, ninety-third yearbook of the national society for the study of education (pp. 174-180). Chicago: University of Chicago Press.

Sacristán-Díaz, M., Garrido-Vega, P., Alfalla-Luque, R., \& María-del-Mar, G. Z. (2016). The effects of teaching and assessment methods on academic performance: a study of an Operations Management course. Innovations in Education and Teaching International, 53(5), 497-507. https://doi.org/10.1080/14703297.2015.1008546

Schuijers, J. A., McDonald, S. J., Julien, B. L., Lexis, L. A., Thomas, C. J., Chan, S., \& Samiric, T. (2013). The effectiveness of separating theory and practicum as a conduit to learning physiology. Advance Physiological Education, 37, 153-156. https:// doi.org/10.1152/advan.00161.2012

Shelena, S.N., Mazniha, B., \& Rosni, R. (2017). Rubric for measuring psychomotor and affective learning domain. Pertanika Journal Social Science \& Humanities, 25(S), 101108.

Smith, P., \& Ragan, T. J. (1999). Instructional design. New York: John Wiley \& Sons. 
Strobel, J., Morris, C. W., Klingler, L., Pan, R. C., Dyehouse, M., \& Weber, N. (2011). Engineering as a caring and empathetic discipline: Conceptualizations and comparisons. Proceedings of the Research in Engineering Education Symposium 2011-Madrid.

Suskie, L. (2004). Assessing student learning. Bolton, MA: Anker.

The Glossary of Education Reform. (2015). Assessment. Retrieved from: https://www.edglossary.org/assessment/

University of New South Wales. (2017, April 18). Using assessment rubrics. Retrieved from: https://teaching.unsw.edu.au/printpdf/546

Vergis, A., \& Hardy, K. (2009). Principles of assessment: A primer for medical educators in the clinical years. International Journal of Medical Education, 1(1), 1-9. https://doi.org/10.5580/2720

\section{Appendix 1}

\section{Survey questions for students' perception}

Part A: Overall perception of the course

1) This course has increased my knowledge related to the field of my study

2) The content of this course is relevant to the field of my study

3) The method of assessments has enhanced my ability to study

\section{Part B: Teaching and Learning Activities}

1) The lecturer/instructor actively encourage the students' involvement in the learning process.

2) The lecturer/instructor know how to deliver the lecture/ knowledge in an interesting way

3) The lecture/instructor help students to grasp the knowledge and understanding of the content of the course 